\title{
Fatty Acids of Triglycerides and Phospholipids from a Thermotolerant Strain of Candida tropicalis Grown on $n$-Alkanes at 30 and $40{ }^{\circ} \mathrm{C}$
}

\author{
By R. F. THORPE AND C. RATLEDGE \\ Department of Biochemistry, The University of Hull, \\ Kingston upon Hull, Yorkshire, HU6 ${ }_{7} R X$
}

(Received 30 March 1973)

INTRODUCTION

The factors responsible for heat resistance in thermophilic organisms have been extensively studied but without conclusive results. Certain biochemical differences have been found between thermophilic and mesophilic micro-organisms: ribosomes (Bubela \& Holdsworth, I966), ribosomal RNA (Friedman, Axel \& Weinstein, I967) and certain cytoplasmic proteins (Farrell \& Campbell, I969) show a correlation between heat stability and maximum growth temperature. Lipids become more saturated at higher growth temperatures (Kates \& Baxter, 1962; Brown \& Rose, I969; Cullen, Phillips \& Shipley, I97I) and the degree of saturation of membrane lipids could, perhaps, determine the maximum and minimum growth temperatures for micro-organisms (Heilbrunn, 1924; Gaughran, 1947). Marr \& Ingraham (I962), however, did not agree with this proposal. With $n$-alkane-utilizing yeasts, which contain a wide range of fatty acids varying in both unsaturation and carbon chain length depending on the composition of the $n$-alkane substrate, there is perhaps greater opportunity for the organism to modify its fatty acid composition than in other yeasts. We have therefore examined the fatty acids of a thermotolerant, hydrocarbon-utilizing yeast to see what changes occur between different growth temperatures.

\section{METHODS}

Organisms and growth. Candida tropicalis used in this work, is a thermotolerant strain that grows at $40{ }^{\circ} \mathrm{C}$. It was grown in batch culture in a stirred fermenter on a basal salts medium similar to that of Jenkins, Raboin \& Moran (1972) with a C13 to C18 fraction of $n$-alkanes as carbon source. The $\mathrm{pH}$ was maintained at 5.5 throughout growth.

Extraction and fractionation of lipids. Lipids were extracted from freeze-dried yeast as described by Thorpe \& Ratledge (I972) and, after removing non-lipid material by passage of the crude lipid down a column of Sephadex G-25 according to Wuthier (I966), were fractionated into neutral and polar lipids on a column of silicic acid by using chloroform ( 5 column volumes) to elute neutral lipids and methanol ( 5 column volumes) to elute polar lipids (Rouser, Kritchevsky \& Yamamoto, 1967).

Further lipid separation was by thin-layer chromatography: neutral lipids were separated and quantitated as described by Thorpe \& Ratledge (1972). Polar lipids were separated by using the solvent system chloroform + methanol + acetic acid + water (25:15:4:2, by vol.). Lipids were detected by exposure of plates to $I_{2}$ vapour (Mangold \& Malins, I966) or spraying with alcoholic Rhodamine 6G solution (Wagner, Hörhammer \& Wolff, I96I). Phospholipids were detected by a molybdenum blue reagent (Dittmer \& Lester, 1964) and a 
Table I. Fatty acids and lipids of Candida tropicalis grown on n-alkanes

\begin{tabular}{|c|c|c|c|c|c|c|}
\hline \multirow[b]{2}{*}{$\begin{array}{c}\text { Growth } \\
\text { temp. } \\
\left({ }^{\circ} \mathrm{C}\right)\end{array}$} & \multicolumn{5}{|c|}{ (a) Lipid compositions } & \\
\hline & $\begin{array}{c}\text { Total } \\
\text { lipid } \\
\text { (\% dry wt) }\end{array}$ & $\begin{array}{c}\text { Sterol } \\
\text { esters }+ \\
\text { hydrocarbons }\end{array}$ & $\begin{array}{c}\text { Triglyce- } \\
\text { rides }\end{array}$ & Unknown* & $\begin{array}{c}\text { Sterol+ } \\
\text { partial } \\
\text { glycerides }\end{array}$ & $\begin{array}{l}\text { Phospho- } \\
\text { lipids }\end{array}$ \\
\hline 40 & 14.9 & $6 \cdot 4$ & 10.9 & $9 \cdot 6$ & $5 \cdot 1$ & 68 \\
\hline 30 & $15 \cdot 5$ & $8 \cdot \mathrm{I}$ & $5 \cdot 2$ & $8 \cdot 4$ & $7 \cdot 3$ & $7 \mathrm{~J}$ \\
\hline
\end{tabular}

(b) Fatty-acid composition

\begin{tabular}{|c|c|c|c|c|}
\hline \multirow[b]{3}{*}{ Fatty acid } & \multicolumn{3}{|c|}{ Growth temp $\left({ }^{\circ} \mathrm{C}\right)$} & \\
\hline & \multicolumn{2}{|c|}{40} & 30 & \\
\hline & Triglycerides & Phospholipids & Triglycerides & Phospholip \\
\hline \multicolumn{5}{|c|}{ Mole $\%$ of fatty acids } \\
\hline $7: 0$ & -- & - & - & $0 \cdot I$ \\
\hline $8: 0$ & - & - & - & 0.2 \\
\hline $9: 0$ & - & - & -- & 0.3 \\
\hline $10: 0$ & - & - & $2 \cdot 9$ & $\mathrm{I} \cdot 8$ \\
\hline II $: 0$ & -. & - & 0.7 & $3 \cdot 6$ \\
\hline $12: 0$ & - & - & - & $O \cdot I$ \\
\hline I2:I & - & - & - & 0.4 \\
\hline $13: 0$ & I.O & 0.2 & $8 \cdot I$ & $r \cdot 7$ \\
\hline $14: 0$ & $5 \cdot 3$ & $\mathrm{I} \cdot 7$ & $4 \cdot 3$ & $I \cdot 5$ \\
\hline $15: 0$ & $15 \cdot 9$ & $8 \cdot 8$ & $9 \cdot 5$ & 6.4 \\
\hline $15: 1$ & O.I & 0.4 & - & 0.4 \\
\hline $16: 0$ & $3 I \cdot 4$ & 18.6 & $2 \mathrm{I} \cdot 8$ & $15 \cdot 6$ \\
\hline $16: 1$ & $6 \cdot 5$ & $14 \cdot 2$ & $9 \cdot 5$ & II $\cdot 8$ \\
\hline $17: 0$ & 17.3 & $6 \cdot 3$ & I $2 \cdot 4$ & $7 \cdot 0$ \\
\hline $17: 1$ & 14.8 & $27 \cdot 0$ & $14 \cdot 2$ & I $8 \cdot 4$ \\
\hline $18: 0$ & 3.6 & $12 \cdot 7$ & $10 \cdot 2$ & $\begin{array}{l}13.8 \\
\end{array}$ \\
\hline I $8: 1$ & $2 \cdot 9$ & $4 \cdot 4$ & 2.8 & $4 \cdot 3$ \\
\hline $18: 2$ & 0.9 & $5 \cdot 7$ & $2 \cdot 9$ & $7 \cdot 2$ \\
\hline $19: 0$ & - & - & 0.7 & $3 \cdot I$ \\
\hline $18: 3$ & - & - & - & $\mathrm{I} \cdot 9$ \\
\hline $\begin{array}{l}\text { Total saturated } \\
\text { acids }(\%)\end{array}$ & 73.8 & $48 \cdot 3$ & $70 \cdot 6$ & $55 \cdot 9$ \\
\hline $\begin{array}{l}\text { Hypothetical mean } \\
\text { melting-point }\left({ }^{\circ} \mathrm{C}\right)\end{array}$ & $46 \cdot r$ & $32 \cdot 8$ & $42 \cdot 5$ & $34 \cdot I$ \\
\hline
\end{tabular}

ninhydrin spray was used to detect lipids having a free amine group (Skipski, Peterson \& Barclay, 1962).

Fatty-acid methyl esters were prepared directly from lipids by using a modified form of the method of Marinetti (1962). Gas-liquid chromatography of the esters was with a Hewlett Packard $7620 \mathrm{~A}$ gas chromatograph, equipped with an integrator, with a column containing I0 \% diethylene glycol succinate on Chromosorb W.

Hypothetical mean melting-point. Because comparing lipids with different fatty-acid compositions is difficult, and the previously adopted concept of calculating the number of double bonds/mole of acid (Kates \& Baxter, 1962) does not allow for changes in fatty-acid chain length, we have calculated from the relative percentages of the individual fatty acids and their respective melting-points a mean melting-point for the fatty-acid mixture: $\Sigma$ m.p. of acid $\times$ relative abundance/ 100 . 


\section{RESULTS}

The lipids of Candida tropicalis were determined after growth at 30 and $40{ }^{\circ} \mathrm{C}$. Although there were only small changes in total lipid contents and in the contents of neutral and polar lipids between samples of the yeast grown at the two temperatures, the amount of triglyceride in the neutral-lipid fraction was halved at the lower growth temperature with a corresponding increase in the sterol and sterol-ester content (Table 1 ). The change in amount of triglyceride was reflected in the change in fatty-acid distribution: a higher proportion of shorter-chain fatty acids ( $\mathrm{CI}_{4}$ and below) and saturated acids were produced at the lower growth temperature with the result that a calculated hypothetical mean melting point for the mixture of acids was decreased by about $4{ }^{\circ} \mathrm{C}$. The fatty acids within the total phospholipids also changed in distribution on lowering the growth temperature, but the decreases in unsaturated acids were compensated for by the increases in shorter-chain acids so that the hypothetical mean melting-points of the fatty-acid mixtures remained almost unchanged.

In the neutral lipids of this yeast an appreciable amount of an unknown material was detected. This material, which had an $R_{F}$ value about 0.7 of that of $R_{\text {triglsceride, was indi- }}$ cated by i.r. and u.v. spectroscopy to be an oxidation product of a polyunsaturated glyceride and may therefore be an artefact arising during harvesting of the yeast and lipid extraction. No change in its percentage proportion of the total lipid was seen at the two growth temperatures.

Only minor changes in phospholipid composition occurred in the yeast grown at $40{ }^{\circ} \mathrm{C}$ and at $30^{\circ} \mathrm{C}$. Phosphatidyl ethanolamine and phosphatidyl choline were the predominant phospholipids with smaller amounts of two phospholipids tentatively identified by spray reagents and $R_{F}$ values, as phosphatidyl serine (or lysophosphatidyl ethanolamine) and lysophosphatidyl serine.

\section{DISCUSSION}

Candida tropicalis, like other yeasts, usually contains only about $30 \%$ of the total fatty acids from phospholipids as saturated acids, though in the triglyceride fraction the content of saturated acids may be up to $60 \%$ (Thorpe \& Ratledge, 1972; Thorpe, 1973). With the present thermotolerant strain of $C$. tropicalis there was an unusually high content of saturated acids in both these lipid fractions even at the lower growth temperature of $30{ }^{\circ} \mathrm{C}$. If this reflects a genuine decreased ability to synthesize unsaturated acids, conformation of the membrane, with its high content of phospholipids, might only reach optimum dynamics at elevated temperatures where a high content of saturated acids would then be beneficial to its structural and functional roles. This may therefore be an explanation for the maximum growth temperature of this yeast being higher than is usually encountered. Greshnykh, Grigorian, Dikanskaja, Diatlovickaja \& Bergelsen (1968), however, have shown in another strain of this yeast, not designated as thermotolerant, that when grown on $n$-alkanes at $38{ }^{\circ} \mathrm{C}$ the concentration of linoleic acid was only $12 \%$ of the total fatty acids, whereas at $28{ }^{\circ} \mathrm{C}$ its concentration was $33 \%$. There are no other reports, as far as we are aware, concerning the effects of temperature on alkane-utilizing yeasts and so it is not possible to judge if our results indicate some intrinsic abnormality of metabolism within this present strain C. tropicalis.

Mobilization of triglycerides, if these are considered as reserve storage materials, will be easier for this yeast to accomplish at $40{ }^{\circ} \mathrm{C}$ than at $30{ }^{\circ} \mathrm{C}$ because a radical change in the fluidity (i.e. melting-point) of the triglycerides apparently cannot be made on lowering the growth temperature. The yeast, however, does attempt to circumvent this constraint by 
producing more shorter-chain acids, which have somewhat similar physical properties to the longer-chain unsaturated acids (Meyer \& Bloch, 1963), though the quantity is insufficient to have much effect on the calculated hypothetical mean melting point.

We thank the Science Research Council for a C.A.P.S. award to R.F.T.

\section{REFERENCES}

Brown, C. M. \& Rose, A. H. (1969). Fatty acid composition of Candida utilis as affected by growth temperature and dissolved oxygen tension. Journal of Bacteriology 99, 37I-378.

Bubela, B. \& Holdsworth, E. S. (1966). Protein synthesis in Bacillus stearothermophilus. Biochimica et biophysica acta I23, 376-389.

Cullen, J., Phillips, M. C. \& Shipley, G. G. (1971). Effects of temperature on composition and physical properties of lipids of Pseudomonas fluorescens. Biochemical Journal 125, 733-742.

DitTMER, J. C. \& Lester, R. L. (1964). Simple specific spray reagent for detection of phospholipids on thinlayer chromatograms. Journal of Lipid Research 5, 126-127.

Farrell, J. \& CAMpbell, L. L. (1969). Thermophilic bacteria and bacteriophages. Advances in Microbial Physiology 3, 83-109.

Friedman, S. M., Axel, R. \& Weinstein, I. B. (1967). Stability of ribosomes and ribosomal ribonucleic acid from Bacillus stearothermophilus. Journal of Bacteriology 93, I521-I526.

GaUghran, E. R. L. (1947). The saturation of bacterial lipids as a function of temperature. Journal of Bacteriology $\mathbf{5 3}, 406$.

Greshnykh, K. P., Grigorian, A. N., Dikanskaja, E. M., Diatlovickaja, E. V. \& Bergelson, L. D. (1968). Effect of temperature and nitrogen source on lipid biosynthesis by yeast grown on $n$-alkanes. (In Russian.) Mikrobiologiya 37, 251-254.

Heilbrunn, L. V. (1924). The heat coagulation of protoplasm. American Journal of Physiology 69, 190-199.

Jenkins, P. G., Raboin, D. \& Moran, F. (1972). Mutants of Mycobacterium rhodochrous with modified patterns of $n$-paraffin utilization. Journal of General Microbiology 72, 395-398.

Kates, M. \& BAXTER, R. M. (I962). Lipid composition of mesophilic and psychrophilic yeasts (Candida species) as influenced by environmental temperature. Canadian Journal of Biochemistry and Physiology 40, $1213-1227$.

MANGOLD, H. K. \& Malins, D. C. (1966). Fractionation of fats, oils and waxes on thin layers of silicic acid. Journal of American Oil Chemists' Society 47, 383-385.

MARINETTI, G. (1962). Chromatographic separation, identification and analysis of phosphatides. Journal of Lipid Research 3, I-20.

MARR, A. G. \& INGRAHAM, J. L. (1962). Effect of temperature on the composition of fatty acids in Escherichia coli. Journal of Bacteriology 84, I260-1 267.

MEYER, F. \& BLOCH, K. (1963). Metabolism of stearolic acid in yeast. Journal of Biological Chemistry 238, $2654-2659$.

Rouser, G., Kritchevsky, G. \& YAMAmoto, A. (1967). Column chromatographic and associated procedures for separation and determination of phosphatides and glycolipids. In Lipid Chromatographic Analysis, pp. 99-I62. Edited by G. Marinetti. London: Edward Arnold.

Skipski, V. P., Peterson, R. F. \& Barclay, M. (1962). Separation of phosphatidyl ethanolamine, phosphatidyl serine, and other phospholipids by thin-layer chromatography. Journal of Lipid Research 3, 467-470.

THORPE, R. F. (1973). Triglyceride structure and biosynthesis in n-alkane utilizing yeasts. Ph.D. Thesis, The University of Hull.

Thorpe, R. F. \& RATLedGe, C. (1972). Fatty acid distribution in triglycerides of yeasts grown on glucose or n-alkanes. Journal of General Microbiology 72, I5I-I63.

WaGner, H., Hörhammer, L. \& WolfF, P. (196I). Dünnschichtchromatographie von Phosphatiden und Glykolipiden. Biochemische Zeitschrift 334, $175-184$.

WuthiER, R. E. (1966). Purification of lipids from nonlipid contaminants on Sephadex bead columns. Journal of Lipid Research 7, 558-56I. 